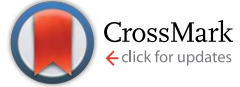

Cite this: RSC Adv., 2017, 7, 16644

Received 21st November 2016 Accepted 27th February 2017

DOI: $10.1039 / c 6 r a 27094 h$

rsc.li/rsc-advances

\section{An organocatalytic method for the synthesis of some novel xanthene derivatives by the intramolecular Friedel-Crafts reaction $\uparrow$}

\author{
Tülay Yıldız* and Hatice Başpinar Küçük
}

An efficient organocatalytic method for the synthesis of new substituted 9-arylxanthenes $(2 a-2 u)$ starting from diarylcarbinol compounds with an arenoxy group (1a-1u) has been developed using the intramolecular FriedelCrafts reaction. The substrates were prepared in two steps by Ullmann-type coupling and then Grignard reaction. Some organic Brønsted acids were studied as catalysts $(3 a-3 g)$ in the intramolecular Friedel-Crafts alkylation reaction for the first time. $N$-triflylphosphoramide $(3 \mathrm{~g})$ provided the synthesis of some novel substituted 9-arylxanthenes with excellent yields at room temperature within 15 minutes.

\section{Introduction}

Xanthenes and their derivatives have biological characteristics; they are used against inflammatory diseases and to treat illnesses caused by viruses and bacteria. ${ }^{1}$ Thus, xanthenes are pharmaceutically active and used in photodynamic therapy. ${ }^{2}$ They are used also as fluorescent materials or dyes and molecular switches, which occur in natural products. ${ }^{3}$ The structure of xanthenes being straight and strict is advantageous; they are used as linkers in peptide syntheses and in the synthesis of unnatural amino acids. ${ }^{4}$ The HIV-1 nucleocapsid protein has around 2000 small molecules (the NCI Diversity Set), in which 26 of them are active inhibitors and five of them were reported to have a xanthenyl ring. ${ }^{5}$

Many synthetic routes to obtain xanthene derivatives have been reported. ${ }^{6}$ The most important examples are the ironcatalysed cascade benzylation-cyclisation of phenols, ${ }^{7} \mathrm{Pd}-$ catalyzed cyclisation of polycyclic aryltriflate esters, ${ }^{8}$ Lewis acid-catalysed cyclisation of salicylaldehydes and cyclohexenones or tetralones, ${ }^{9}$ and the condensation of 2-naphthol and numerous aryl aldehydes. ${ }^{10}$ The synthesis of substituted 9arylxanthenes using the tandem arylation/Friedel-Crafts reaction of $O$-hydroxy bisbenzylic alcohols with diaryliodonium salts was recently reported by Wang et al. ${ }^{\mathbf{1 1}}$ Another study concerning the synthesis of substituted 9-arylxanthenes reported an $\mathrm{Sc}(\mathrm{OTf})_{3}$-catalyzed domino reaction. ${ }^{\mathbf{1 2}}$ Additionally some nitrogen or sulphur-containing xanthene derivatives, which may be used especially as antitumor agents, were synthesized in previous works. ${ }^{13}$

Istanbul University, Faculty of Engineering, Department of Chemistry, 34320, Istanbul, Turkey.E-mail: tulayyil@istanbul.edu.tr

$\dagger$ Electronic supplementary information (ESI) available. See DOI: 10.1039/c6ra27094h
We have determined that the most suitable method to obtain 9-arylxanthenes is the intramolecular Friedel-Crafts alkylation (FCA) of proper alcohols because the literature on arylation using an FCA protocol has recently started to see new developments. In particular, arylation that does not use any metals has became a very popular topic for avoiding the disadvantages of organometallic chemistry, which poses high cost, uses toxic materials, and poses difficulties during purification. ${ }^{14}$ These new methods have opened new doors using mild reaction conditions and employing cheap and less toxic catalysts. ${ }^{15}$

In this field, the development of new $\pi$-activated alcohols has increasing importance over the development of organohalides, which are more toxic and require harsh conditions. ${ }^{\mathbf{1 6}}$ Thus, Lautens et al. reported an efficient synthesis of the targeted cis-hexahydrobenzophenanthridines from tetralins, which are very easy to obtain. The reaction included $\pi$-activated alcohols produced using intramolecular FCA in the presence of Lewis acids. ${ }^{17}$ An important work which realised cyclization of $\tau$-activated alcohols by $\mathrm{Bi}(\mathrm{OTf})_{3}$-catalyzed intramolecular FCA was reported by Rueping et al. ${ }^{18}$ To synthesise substituted 9arylxanthenes, another Lewis acid-catalysed intramolecular FCA procedure was carried out by Panda and co-workers in 2009. ${ }^{19}$ In this study, they used well-known FCA catalysts and some Lewis acids like conc. $\mathrm{H}_{2} \mathrm{SO}_{4}$, anhyd. $\mathrm{AlCl}_{3}, \mathrm{FeCl}_{3}, \mathrm{Sc}(\mathrm{OTf})_{3}$ and TfOH. Among the catalysts studied, $\mathrm{FeCl}_{3}$ gave the best result with $91 \%$ yield in dry $\mathrm{CH}_{2} \mathrm{Cl}_{2}$ at room temperature.

According to the literature, although there are reports of hydroarylation reactions of activated alkenes using FCA with Brønsted acids such as diphenyl hydrogen phosphate as the catalysts, ${ }^{20}$ there are no reports of intramolecular FCA using organic Brønsted acids as the catalysts instead of Lewis acids. Considering the recent reports, non-chiral, organic Brønsted "super-acids" are comparable or even better than Lewis or inorganic Brønsted acids. ${ }^{21}$ Furthermore, the organic Brønsted acids are similar to Lewis acids as they are usually stable against 
$\mathrm{CH}_{3} \mathrm{COOH} 3 \mathbf{a}$ $\mathrm{CF}_{3} \mathrm{COOH} \mathbf{3 b}$ $\mathrm{C}_{6} \mathrm{H}_{5} \mathrm{COOH} 3 \mathrm{c}$ $\mathrm{CH}_{3} \mathrm{CHOH}-\mathrm{COOH} 3 \mathrm{~d}$ $\mathrm{p}-\mathrm{MeC}_{6} \mathrm{H}_{4} \mathrm{SO}_{3} \mathrm{H} . \mathrm{H}_{2} \mathrm{O} 3 \mathrm{e}$
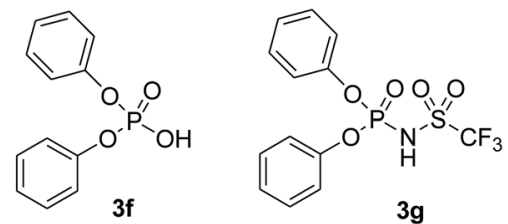

Fig. 1 Structures of used organic Brønsted acids.

oxidizing ambience or humidity, and they can be easily handled and are stable over a long period of time..$^{22}$ Recently, in order to create new types of super acids or super acid catalysts, new Brønsted acids including $=\mathrm{NSO}_{2} \mathrm{CF}_{3}$ or $=\mathrm{NSO}_{2} \mathrm{~F}$ groups were synthesized because these groups increase the acidity substantially. ${ }^{23}$ It is understood that triflate groups in particular, among all acidic compounds, increase the acidity significantly. Due to $N$-triflate groups having lower $\mathrm{p} K_{\mathrm{a}}$ values than normal organic acids, ${ }^{24}$ the more acidic $N$-triflate groups can catalyze the reactions with generally better yields and in less time. As an example of an organic Brønsted acid, $N$-triflylphosphoramide (3g) (Fig. 1) was used in some previous reports. A study on this subject includes the preparation of 1,3dioxolane-4-ones starting from $\alpha$-hydroxy acids and aldehydes with the use of $3 \mathbf{g} .{ }^{25}$ Another example reports a transformation, which has merged the Ugi reaction and Houben-Hoesch cyclisation in the presence of $3 \mathbf{g}^{.26}$ In that report, after several Brønsted and Lewis acids were examined, they found that the acid-promoted reaction is effective in the synthesis of many 3aminoindole molecules using $\mathbf{3 g}$ with high yields and under mild conditions.

In this study, to develop an effective and economic organocatalytic FCA protocol to synthesize some novel substituted arylxanthenes under mild conditions, we explored some organic Brønsted acids as catalysts (3a-3g) in the intramolecular FCA reaction for the first time.

We obtained arylxanthenes with excellent yields using $\mathrm{N}$ triflylphosphoramide (3g). Among all synthesised substituted arylxanthenes, seventeen of the compounds are novel, and the others, $2 \mathbf{i},{ }^{27} 2 \mathbf{j},{ }^{27}$ and $2 \mathbf{k},{ }^{19}$ have been synthesised previously with different methods.

\section{Results and discussion}

Our starting materials were synthesised in two steps involving metal-free Ullmann coupling ${ }^{28}$ and then Grignard reaction. Finally, we obtained diarylcarbinol compounds including an arenoxy group as the starting material with very high yields (95-100\%). All starting compounds (diarylcarbinols) are novel except $\mathbf{1 k} .^{19}$

We have chosen carbinol 1a in order to examine the catalysts and carry out initial optimisation experiments of the intramolecular FCA. Therefore, we explored the different organic Brønsted acids as catalysts for the intramolecular FCA reaction (Table 1). The catalysts we used were acetic acid (3a), trifluoroacetic acid (3b), benzoic acid (3c), L-lactic acid (3d), $p$-toluenesulfonic acid (3e), diphenyl hydrogen phosphate (3f), and $N$ triflylphosphoramide (3g). Firstly, the solution of $1 \mathbf{a}$ and acid catalyst $(3 \mathrm{a}-3 \mathrm{~g})$ in dichloromethane was stirred at $25{ }^{\circ} \mathrm{C}$ until
Table 1 Screening of catalysts for intramolecular FCA of $1 a^{a}$
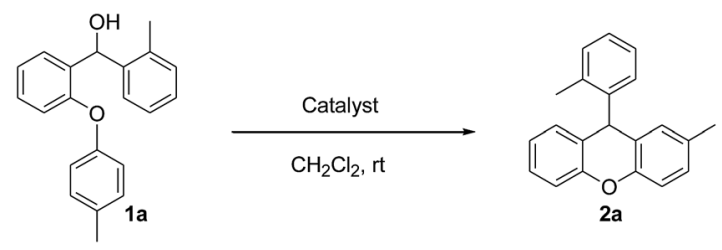

\begin{tabular}{llll}
\hline Entry & Catalyst $(10 \%$ equiv. $)$ & Time & Yield $^{b}(\%)$ \\
\hline 1 & None & $24 \mathrm{~h}$ & $\mathrm{nr}$ \\
2 & 3a & $24 \mathrm{~h}$ & 2 \\
3 & $3 \mathbf{b}$ & $2 \mathrm{~h}$ & 65 \\
4 & 3c & $24 \mathrm{~h}$ & $\mathrm{nr}$ \\
5 & 3d & $24 \mathrm{~h}$ & $\mathrm{nr}$ \\
6 & 3e & $2 \mathrm{~h}$ & 70 \\
7 & $3 \mathbf{f}$ & $24 \mathrm{~h}$ & 5 \\
8 & $3 \mathrm{~g}$ & $2 \mathrm{~h}$ & 78
\end{tabular}

${ }^{a}$ Condition: 1a $(0.1 \mathrm{mmol})$ and catalyst $\left(10 \%\right.$ equiv.) in $\mathrm{CH}_{2} \mathrm{Cl}_{2}(2.5 \mathrm{~mL})$ were stirred at room temperature. ${ }^{b}$ Yield of isolated product.

the starting material was consumed. In this way, the different Brønsted acids were compared against each other for the intramolecular FCA reaction.

Moderate yields were obtained using $\mathbf{3 b}$ and $\mathbf{3 e}$ catalysts (Table 1, entries 3 and 6). 3a and $\mathbf{3 f}$ gave very low yields (Table 1 , entries 2 and 7) despite the long reaction times. Benzoic acid (3c) and L-lactic acid (3d) did not react at all (Table 1, entries 4 and 5). As expected, no conversion was observed in the absence of the catalyst (Table 1, entry 1). Interestingly, the best result was achieved when $10 \mathrm{~mol} \%$ of $\mathbf{3 g}$ was used to obtain the desired product $2 \mathrm{a}$ in $78 \%$ yield within 2 hours (Table 1 , entry 8 ).

In the second phase, we examined the effect of the solvent on the intramolecular FCA reaction 1a using the best catalyst $\mathbf{3 g}$

Table 2 Screening of solvents for intramolecular FCA of $1 a^{a}$
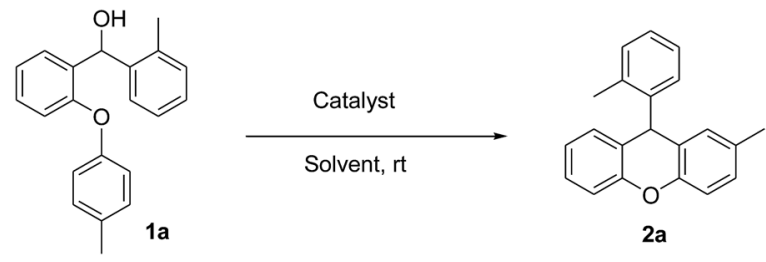

\begin{tabular}{llllll} 
Entry & Catalyst & Solvent & Cat. amount $(\mathrm{mol} \%)$ & Time & Yield $^{b}(\%)$ \\
\hline 1 & $\mathbf{3 g}$ & $\mathrm{CH}_{2} \mathrm{Cl}_{2}$ & 10 & $2 \mathrm{~h}$ & 78 \\
2 & $\mathbf{3 g}$ & Benzene & 10 & $2 \mathrm{~h}$ & 13 \\
3 & $\mathbf{3 g}$ & Toluene & 10 & $2 \mathrm{~h}$ & 17 \\
4 & $\mathbf{3 g}$ & $\mathrm{CHCl}_{3}$ & 10 & $2 \mathrm{~h}$ & 91 \\
5 & $\mathbf{3 g}$ & $\mathrm{THF}$ & 10 & $2 \mathrm{~h}$ & 11 \\
6 & $\mathbf{3 g}$ & $\mathrm{CH}_{3} \mathrm{CN}$ & 10 & $15 \mathrm{~min}$ & $>99$ \\
7 & $\mathbf{3 g}$ & $\mathrm{CH}_{3} \mathrm{CN}$ & 5 & $15 \mathrm{~min}$ & 85 \\
8 & $\mathbf{3 b}$ & $\mathrm{CH}_{3} \mathrm{CN}$ & 10 & $15 \mathrm{~min}$ & 85 \\
9 & $\mathbf{3 e}$ & $\mathrm{CH}_{3} \mathrm{CN}$ & 10 & $15 \mathrm{~min}$ & 87
\end{tabular}

${ }^{a}$ Condition: 1a $(0.1 \mathrm{mmol})$ and catalyst $(10 \% \mathrm{mmol})$ in solvent $(2.5 \mathrm{~mL})$ were stirred at room temperature. ${ }^{b}$ Yield of isolated product. 
(Table 2). Performing the reaction in several solvents gave interesting results. The intramolecular FCA reaction of $\mathbf{1 a}$ with $\mathrm{CH}_{2} \mathrm{Cl}_{2}$ and $\mathrm{CHCl}_{3}$ showed good yields with side products. While THF, benzene and toluene gave very low yields, $\mathrm{CH}_{3} \mathrm{CN}$ provided the best result with $99 \%$ yield and no side reaction when using $10 \mathrm{~mol} \%$ of $\mathbf{3 g}$ (Table 2 , entry 6 ). Also we observed a lower yield when using $5 \mathrm{~mol} \%$ of the catalyst (Table 2, entry 7). Additionally, the other best catalysts $\mathbf{3 b}$ and $\mathbf{3 e}$ were also tested in $\mathrm{CH}_{3} \mathrm{CN}$. However, lower yields of 85 and $87 \%$ were obtained in these reactions (Table 2, entries 8 and 9).

In parallel to our work, it was shown in previous studies that $\mathrm{CH}_{3} \mathrm{CN}$ is a good discriminating solvent for strong acids, because of its weak basicity and weak solvating power to anions. ${ }^{23}$ Therefore we found that performing the cyclisation by intramolecular FCA with $10 \mathrm{~mol} \% 3 \mathrm{~g}$ in $\mathrm{CH}_{3} \mathrm{CN}$ at room temperature for 15 min showed excellent results for obtaining substituted 9-arylxanthene derivatives. After these optimisation reactions, we looked at the differences when we used different aromatic hydroxy compounds $\left(\mathrm{Ar}_{1}\right)$ in the Ullmann coupling reaction. We used different substituent aryl groups including $\mathrm{Me}, \mathrm{Br}, \mathrm{Cl}, \mathrm{F}, \mathrm{CN}, \mathrm{NO}_{2}$ etc. $\left(\mathrm{Ar}_{1}\right)$ during this reaction step and synthesized diaryl compounds that have these substituents on the arenoxy group in order to investigate the effect of the different functional groups on the intramolecular FCA. The other aryl group $p$-methoxy phenyl $\left(\mathrm{Ar}_{2}\right)$ was chosen for use in all substrates for these experiments. The effect of the functional groups on $\mathrm{Ar}_{1}$ screening reactions are summarized in Table 3 .

As can be seen in Table 3, electron donating groups like methyl and naphthyl groups (entries 1 and 2) increase the rate of the electrophilic substitution. Therefore, their yields are excellent during intramolecular FCA. When we look at halogen containing electron withdrawing groups, although they are weakly deactivating, their yields are very good, especially for the 3-Br substituent (Table 3, entry 3). As expected, the other electron withdrawing groups nitro and cyano gave very low yields

Table 3 The effect of the functional groups on $\mathrm{Ar}_{1}$ for intramolecular $\mathrm{FCA}^{a}$

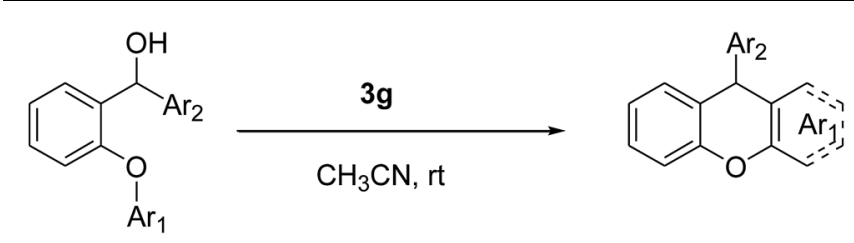

\begin{tabular}{lllll}
\hline Entry & Product & $\mathrm{Ar}_{1}$ & $\mathrm{Ar}_{2}$ & Yield $^{b}(\%)$ \\
\hline 1 & $\mathbf{2 e}$ & $2-\mathrm{MeC}_{6} \mathrm{H}_{4}$ & $4-\mathrm{MeOC}_{6} \mathrm{H}_{4}$ & 96 \\
2 & $\mathbf{2 k}$ & $2-\mathrm{Np}$ & $4-\mathrm{MeOC}_{6} \mathrm{H}_{4}$ & $>99$ \\
3 & $2 \mathbf{p}$ & $3-\mathrm{BrC}_{6} \mathrm{H}_{4}$ & $4-\mathrm{MeOC}_{6} \mathrm{H}_{4}$ & 98 \\
4 & $\mathbf{2 r}$ & $4-\mathrm{ClC}_{6} \mathrm{H}_{4}$ & $4-\mathrm{MeOC}_{6} \mathrm{H}_{4}$ & 95 \\
5 & $2 \mathbf{s}$ & $4-\mathrm{FC}_{6} \mathrm{H}_{4}$ & $4-\mathrm{MeOC}_{6} \mathrm{H}_{4}$ & 75 \\
6 & $2 \mathbf{t}$ & $4-\mathrm{CNC}_{6} \mathrm{H}_{4}$ & $4-\mathrm{MeOC}_{6} \mathrm{H}_{4}$ & 5 \\
7 & $2 \mathbf{u}$ & $4-\mathrm{NO}_{2} \mathrm{C}_{6} \mathrm{H}_{4}$ & $4-\mathrm{MeOC}_{6} \mathrm{H}_{4}$ & 4
\end{tabular}

${ }^{a}$ Condition: carbinol $(0.1 \mathrm{mmol})$ and $3 \mathrm{~g}$ in $\mathrm{CH}_{3} \mathrm{CN}(2.5 \mathrm{~mL})$ were stirred at room temperature. ${ }^{b}$ Yield of isolated product.
Table 4 The effect of the functional groups on $\mathrm{Ar}_{2}$ for intramolecular $\mathrm{FCA}^{a}$

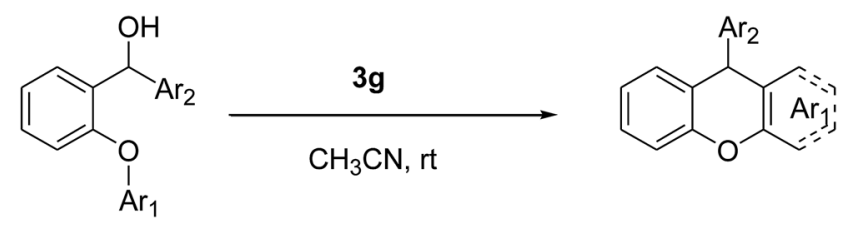

\begin{tabular}{lllll}
\hline Entry & Product & $\mathrm{Ar}_{1}$ & $\mathrm{Ar}_{2}$ (or R) & Yield $^{b}(\%)$ \\
\hline 1 & $\mathbf{2 a}$ & $4-\mathrm{MeC}_{6} \mathrm{H}_{4}$ & $2-\mathrm{MeC}_{6} \mathrm{H}_{4}$ & $>99$ \\
2 & $\mathbf{2 b}$ & $3-\mathrm{MeC}_{6} \mathrm{H}_{4}$ & $4-\mathrm{MeC}_{6} \mathrm{H}_{4}$ & $>99$ \\
3 & $\mathbf{2 c}$ & $2-\mathrm{MeC}_{6} \mathrm{H}_{4}$ & $2-\mathrm{MeC}_{6} \mathrm{H}_{4}$ & 95 \\
4 & $\mathbf{2 d}$ & $2-\mathrm{MeC}_{6} \mathrm{H}_{4}$ & $4-\mathrm{MeC}_{6} \mathrm{H}_{4}$ & 96 \\
5 & $\mathbf{2 e}$ & $2-\mathrm{MeC}_{6} \mathrm{H}_{4}$ & $4-\mathrm{MeOC}_{6} \mathrm{H}_{4}$ & 96 \\
6 & $\mathbf{2 f}$ & $2-\mathrm{MeC}_{6} \mathrm{H}_{4}$ & $2-\mathrm{Np}$ & 88 \\
7 & $\mathbf{2 m}$ & $3-\mathrm{MeC}_{6} \mathrm{H}_{4}$ & $\mathrm{C}_{15} \mathrm{H}_{31}$ & 73 \\
8 & $\mathbf{2 n}$ & $4-\mathrm{MeC}_{6} \mathrm{H}_{4}$ & $2-\mathrm{Thienyl}$ & 79
\end{tabular}

${ }^{a}$ Condition: carbinol $(0.1 \mathrm{mmol})$ and $3 \mathrm{~g}(10 \% \mathrm{mmol})$ in $\mathrm{CH}_{3} \mathrm{CN}(2.5 \mathrm{~mL})$ were stirred at room temperature. ${ }^{b}$ Yield of isolated product.

(Table 3, entries 6 and 7), because of their strongly deactivating effect in the electrophilic aromatic substitution reactions.

Following this, various arylmagnesium bromides $\left(\mathrm{Ar}_{2}\right)$ were used in the Grignard reaction step. When $\mathrm{Ar}_{1}$ was kept as an $\mathrm{Me}$ group with different positions and $\mathrm{Ar}_{2}$ (or $\mathrm{R}$ ) was changed with different groups and positions (Table 4), we observed that $\mathrm{CH}_{3}$ and $\mathrm{CH}_{3} \mathrm{O}$ groups showed almost the same yield with 99-95\% (entries 1-5). In addition, the position of the Me group on the $\mathrm{Ar}_{1}$ did not significantly affect the reaction. The naphthyl and thienyl groups resulted in slightly lower yields of 88 and $79 \%$ (Table 4, entries 6 and 8). When a long chain alkyl group was used instead of $\mathrm{Ar}_{2}$, the yield was only $73 \%$ (Table 4, entry 7). Consequently, the $\mathrm{Ar}_{1}$ group is more effective than the $\mathrm{Ar}_{2}$ group in this reaction (FCA) because the $\mathrm{Ar}_{1}$ group is part of the mechanism of the reaction.

The well known SN1 type intramolecular Friedel-Crafts alkylation mechanism can be shown for our compounds (Scheme 1).

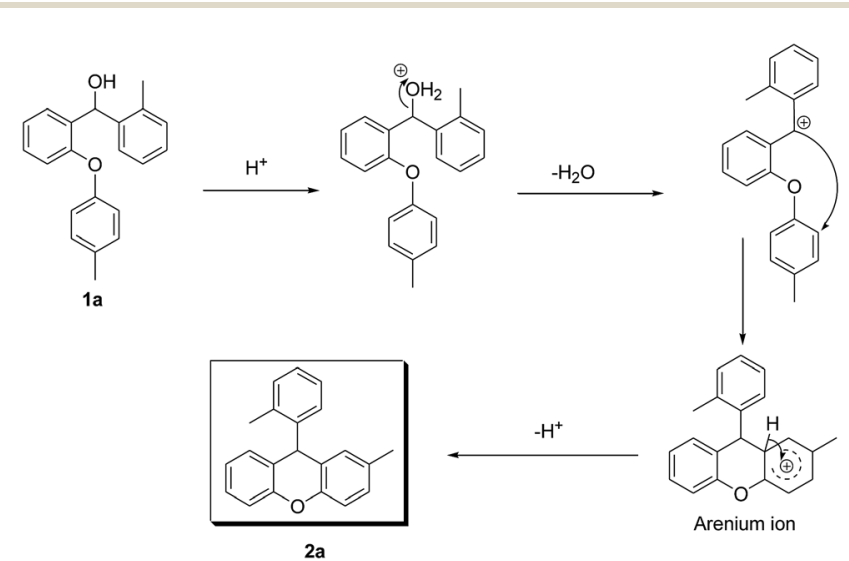

Scheme 1 Proposed Brønsted acid-mediated intramolecular FriedelCrafts alkylation mechanism of 1 a. 
In the proposed mechanism, after protonation of the starting material 1a, a water molecule leaves and the carbocation anion is formed. Following this, the carbocation anion attacks the other aryl functional group and the arenium ion is produced. Finally, a proton is lost from the arenium ion and the cyclisation is completed to give the desired product $\mathbf{2 a}$. The new ring formed is very stable because it is six membered.

In addition, although the mechanism that we have proposed is an SN1 type Friedel-Crafts mechanism, an ortho-quinonemethide $(o-\mathrm{QM})$ intermediate may also be composed in the presence of the acidic media. Recently, Rueping et al. studied

Table 5 Scope of substrates for intramolecular FCA of $1 a-1 u$ and their yields ${ }^{a b}$

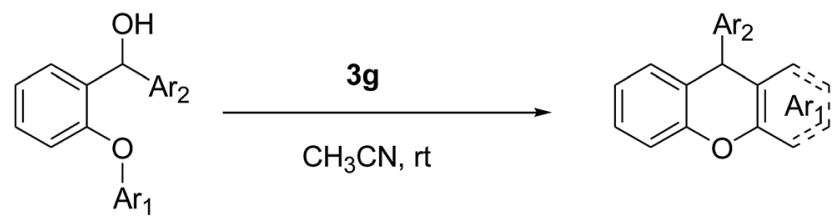

$1 \mathrm{a}-1 \mathrm{u}$

$2 a-2 u$<smiles>Cc1ccc2c(c1)C(c1ccccc1C)c1ccccc1O2</smiles>

$2 \mathrm{a}>99 \%$<smiles>COc1ccc(C2c3ccccc3Oc3c(C)cccc32)cc1</smiles>

2e $96 \%$<smiles>Cc1ccccc1C1c2ccccc2Oc2ccc3ccccc3c21</smiles>

$2 \mathbf{i}>99 \%$

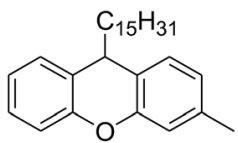

$2 \mathrm{~m} 73 \%$<smiles>COc1ccc(C2c3ccccc3Oc3ccc(Cl)cc32)cc1</smiles>

2r 95\%<smiles>Cc1ccc(C2c3ccccc3Oc3cc(C)ccc32)cc1</smiles>

$2 b>99 \%$<smiles>Cc1cccc2c1Oc1ccccc1C2c1ccc2ccccc2c1</smiles>

$2 f 88 \%$<smiles>Cc1ccc(C2c3ccccc3Oc3ccc4ccccc4c32)cc1</smiles>

2j >99\%<smiles>Cc1ccc2c(c1)C(c1cccs1)c1ccccc1O2</smiles>

2n $79 \%$<smiles>COc1ccc(C2c3ccccc3Oc3ccc(F)cc32)cc1</smiles>

2s $75 \%$<smiles>Cc1ccccc1C1c2ccccc2Oc2c(C)cccc21</smiles>

2c $95 \%$<smiles>Cc1ccc2c(c1)Oc1ccccc1C2c1ccc2ccccc2c1</smiles>

2g $98 \%$<smiles>COc1ccc(C2c3ccccc3Oc3ccc4ccccc4c32)cc1</smiles>

$2 \mathbf{k}>99 \%$<smiles>c1csc(C2c3ccccc3Oc3ccc4ccccc4c32)c1</smiles>

$2090 \%$<smiles>COc1ccc(C2c3ccccc3Oc3ccc(C#N)cc32)cc1</smiles><smiles>Cc1ccc(C2c3ccccc3Oc3c(C)cccc32)cc1</smiles>

2d $96 \%$<smiles>Cc1ccc2c(c1)C(c1ccc3ccccc3c1)c1ccccc1O2</smiles>

2h $85 \%$<smiles>c1ccc2c(c1)Oc1ccc3ccccc3c1C2c1ccc2ccccc2c1</smiles>

2l $>99 \%$<smiles>COc1ccc(C2c3ccccc3Oc3cc(Br)ccc32)cc1</smiles>

$2 p>99 \%$<smiles>COc1ccc(C2c3ccccc3Oc3ccc([N+](=O)[O-])cc32)cc1</smiles>

2u $4 \%$

${ }^{a}$ Condition: 1a-1u $(0.1 \mathrm{mmol})$ and $\mathbf{3} \mathbf{g}(10 \%$ equiv. $)$ in $\mathrm{CH}_{3} \mathrm{CN}(2.5 \mathrm{~mL})$ were stirred at room temperature for $15-60$ min. ${ }^{b}$ Yield of isolated product. 
this mechanism with asymmetric Brønsted acids. ${ }^{29}$ In these works, a possible transition-state model was proposed in order to describe the mechanism of some Brønsted acid catalysed reactions via multiple hydrogen-bond interplay between the chiral catalyst and substrate.

\section{Experimental}

\section{General information}

The majority of the chemicals used in this work were commercially available from Merck or Aldrich. $\mathrm{CH}_{3} \mathrm{CN}$ was purchased from Merck with catalog number 114291. It has $99.8 \%$ purity and was not additionally dried. The starting carbinols 1a-1u were prepared by Ullmann coupling of 2-fluorobenzaldehyde and substituted phenols, and then by the Grignard reaction of 2-arenoxybenzaldehydes and some arylmagnesium bromides. All substrates were purified by crystallization or column chromatography and characterized by IR, ${ }^{1} \mathrm{H}$ NMR, and ${ }^{13} \mathrm{C}-\mathrm{NMR}$ spectroscopy, elemental analysis and GCMS. All novel products were characterized by IR, ${ }^{1} \mathrm{H}-\mathrm{NMR}$, and ${ }^{13} \mathrm{C}-\mathrm{NMR}$ spectroscopy, elemental analysis and GC-MS. The reactions were monitored by TLC using silica gel plates and the products were purified by flash column chromatography on silica gel (Merck; 230-400 mesh), eluting with hexane-ethyl acetate (v/v $9: 1)$. The NMR spectra were recorded at $500 \mathrm{MHz}$ for ${ }^{1} \mathrm{H}$ NMR and $125 \mathrm{MHz}$ for ${ }^{13} \mathrm{C} \mathrm{NMR}$ using $\mathrm{Me}_{4} \mathrm{Si}$ as the internal standard in $\mathrm{CDCl}_{3}$. The GC-MS were recorded on a Shimadzu/QP2010 Plus. The IR spectra were recorded on a Mattson 1000 spectrometer. The melting points were determined with a Büchi Melting Point B-540.

\section{General procedure for intramolecular Friedel-Crafts cyclization}

Under room temperature conditions, $N$-triflylphosphoramide (3g) (10 mol\%) was added to a stirred solution of a starting alcohol compound (1a-1m) $(0.1 \mathrm{mmol})$ in $\mathrm{CH}_{3} \mathrm{CN}(2.5 \mathrm{~mL})$, and the reaction was stirred for $15 \mathrm{~min}$. After the completion of the reaction, as observed with TLC, the mixture was concentrated in a vacuum and extracted with ethylacetate. After the usual reaction workup and concentration, the product was charged on silica gel.

\section{Conclusions}

In conclusion, an efficient synthetic method was developed for the synthesis of new substituted 9-arylxanthenes via intramolecular Friedel-Crafts cyclisation, using non-transition metal organocatalysis, and starting from diarylcarbinol compounds. In this work, we looked for an optimisation of the reaction conditions to yield highly efficient 9-arylxanthene synthesis. Thus, we examined some organic Brønsted-acids as catalysts and determined the best catalyst for intramolecular FCA. We found that $N$-triflylphosphoramide $(\mathbf{3 g})$ as a catalyst is highly effective, inexpensive and non-toxic for the rapid synthesis of xanthenes in $\mathrm{CH}_{3} \mathrm{CN}$ at room temperature, when compared to previous intramolecular FCA reactions and the synthesis of 9-arylxanthenes.

Finally, we determined a new organocatalytic FCA protocol, which does not require inert reaction conditions or any protection, to synthesise some novel substituted arylxanthenes using $\mathbf{3 g}$ with excellent yields. The twenty newly synthesised substituted 9-arylxanthenes 2a-2u (Table 5) may be used as natural and bio-active compounds, dyes or fluorescent materials, and their biochemical properties and activities will be investigated in the future.

\section{Acknowledgements}

This work was supported by Istanbul University, Scientific Research Projects, project numbers BYP 41636 and BYP 53627.

\section{Notes and references}

1 J. P. Poupelin, G. Saint-Ruf, O. Foussard-Blanpin, G. Narcisse, G. Uchida-Ernouf and R. Lacroix, Eur. J. Med. Chem., 1978, 13, 67; R. W. Lambert, J. A. Martin, J. H. Merrett, K. E. B. Parkes and G. J. Thomas, Int. Appl., WO 9706178, 1997.

2 A. Banerjee and A. K. Mukherjee, Stain Technol., 1981, 56, 83.

3 M. S. T. Gonçalves, Chem. Rev., 2008, 109, 190; B. L. Feringa, J. Org. Chem., 2007, 72, 6635.

4 N. P. Buu-Hoi, G. Saint-Ruf, A. De and H. T. Hieu, Bull. Chim. Ther., 1972, 7, 83.

5 A. G. Stephen, K. M. Worthy, E. Towler, J. A. Mikovits, S. Sei, P. Roberts, Q. Yang, R. K. Akee, P. Klausmeyer, T. G. McCloud, L. Henderson, A. Rein, D. G. Covell, M. Currens, R. H. Shoemaker and R. J. Fisher, Biochem. Biophys. Res. Commun., 2002, 296, 1228.

6 H. Li, J. Yang, Y. Liu and Y. Li, J. Org. Chem., 2009, 74, 6797; K. Okuma, K. Nojima, N. Matsunaga and K. Shioji, Org. Lett., 2009, 11, 169; J. Zhao and R. C. Larock, J. Org. Chem., 2007, 72, 583; J. Zhao and R. C. Larock, Org. Lett., 2005, 7, 4273.

7 X. Xu, X. Xu, H. Li, X. Xie and Y. Li, Org. Lett., 2010, 12, 100. 8 J.-Q. Wang and R. G. Harvey, Tetrahedron, 2002, 58, 5927.

9 E. Bö $\beta$, T. Hillringhaus, J. Nitsch and M. Klussmann, Org. Biomol. Chem., 2011, 9, 1744.

10 K. R. M. Naidu, B. S. Krishna, M. A. Kumar, P. Arulselvan, S. I. Khalivulla and O. Lasekan, Molecules, 2012, 17, 7543; G. M. Ziarani, A.-R. Badiei and M. Azizi, Sci. Iran., Trans. C, 2011, 18, 453.

11 S. Mao, Z. Hua, X. Wu, Y. Yang, J. Han and L. Wang, Chemistry Select, 2016, 3, 403.

12 R. Singh and G. Panda, Org. Biomol. Chem., 2010, 8, 1097.

13 R. A. Al-Qawasmeh, Y. Lee, M.-Y. Cao, X. Gu, S. Viau, J. Lightfoot, J. A. Wright and A. H. Young, Bioorg. Med. Chem. Lett., 2009, 19, 104; S. Ohno, H. Shimizu, T. Kataoka and M. Hori, Chem. Pharm. Bull., 1984, 32, 3471.

14 E. Shirakawa, K. Itoh, T. Higashino and T. Hayashi, J. Am. Chem. Soc., 2010, 132, 15537; S. Yanagisawa, K. Ueda, T. Taniguchi and K. Itami, Org. Lett., 2008, 10, 4673.

15 X. Zhang, W. Rao and S. Wai Hong Chan, Org. Biomol. Chem., 2009, 7, 4186; X. Deng, J. T. Liang, J. Liu, H. McAllister, 
C. Schubert and N. S. Mani, Org. Process Res. Dev., 2007, 11, 1043; A. S. K. Hashmi, L. Schwarz, P. Rubenbauer and M. C. Blanco, Adv. Synth. Catal., 2006, 348, 705.

16 E. Emer, R. Sinisi, M. G. Capdevila, D. Petruzziello, F. De Vincentis and P. Cozzi, Eur. J. Org. Chem., 2011, 4, 647; M. Bandini and M. Tragni, Org. Biomol. Chem., 2009, 7, 1501; J. Muzart, Tetrahedron, 2008, 64, 5815.

17 C. Liebert, M. K. Brinks, A. G. Capacci, M. J. Fleming and M. Lautens, Org. Lett., 2011, 13, 3000.

18 M. Rueping, B. J. Nachtsheim and W. Ieawsuwan, Adv. Synth. Catal., 2006, 348, 1033.

19 S. K. Das, R. Singh and G. Panda, Eur. J. Org. Chem., 2009, 28, 4757.

20 I. Fleischer and J. Pospech, RSC Adv., 2015, 5, 493.

21 M. Rueping, B. J. Nachtsheim, W. Ieawsuwan and I. Atodiresei, Angew. Chem., Int. Ed., 2011, 50, 6706; K. Kaupmees, N. Tolstoluzhsky, S. Raja, M. Rueping and I. Leito, Angew. Chem., Int. Ed., 2013, 52, 11569;
M. Rueping, B. J. Nachtsheim, S. A. Moreth and M. Bolte, Angew. Chem., Int. Ed., 2008, 47, 593.

22 T. Akiyama, Chem. Rev., 2007, 107, 5744.

23 L. M. Yagupolskii, V. N. Petrik, N. V. Kondratenko, L. Sooväli, I. Kaljurand, I. Leito and I. A. Koppel, J. Chem. Soc., Perkin Trans. 2, 2002, 2, 1950.

24 M. Rueping, B. J. Nachtshe, R. M. Koenigs and W. Ieawsuwan, Chem.-Eur. J., 2010, 16, 13116.

25 H. B. Küçük, Tetrahedron Lett., 2015, 56, 5583.

26 J. S. Schneekloth Jr, J. Kim and E. J. Sorensen, Tetrahedron, 2009, 65, 3096.

27 R. Dada, G. Singh, A. Pareek, S. Kausar and S. Yaragorla, Tetrahedron Lett., 2016, 57, 3739.

28 G. W. Yeager and D. N. Schissel, Synthesis, 1995, 1, 28.

29 C.-C. Hsiao, S. Raja, H.-H. Liao, I. Atodiresei and M. Rueping, Angew. Chem., Int. Ed., 2015, 54, 576; C.-C. Hsiao, H.-H. Liao and M. Rueping, Angew. Chem., Int. Ed., 2014, 53, 13258. 